\title{
UN ESBOZO COMPARATIVO DE LA ENSAYÍSTICA DE ZBIGNIEW HERBERT CON TEXTOS HISPÁNICOS
}

\author{
Amán Rosales Rodríguez \\ Uniwersytet im. Adama Mickiewicza w Poznaniu \\ Instytut Filologii Romańskiej \\ Uniwersytet Łódzki \\ Katedra Filologii Hiszpańskiej
}

Resumen. Se propone una relectura de algunos ensayos de Zbigniew Herbert con base en una comparación con textos de Octavio Paz y Rafael Argullol. Se comentan los siguientes temas: características del ensayo literario, el viaje como desplazamiento geográfico y experiencia espiritual, la relación entre individuo e historia, y la visión moderadamente escéptica de la cultura occidental, presente, en distintos grados, en los tres autores.

Palabras clave: ensayo literario, literatura de viajes, ensayo polaco, ensayo español, ensayo hispanoamericano.

\section{A COMPARATIVE SKETCH OF THE ESSAYS OF ZBIGNIEW HERBERT WITH HISPANIC TEXTS}

\begin{abstract}
A re-reading of some of Zbigniew Herbert's essays is proposed in base of a comparison with texts by Octavio Paz and Rafael Argullol. The following topics are commented: characteristics of the literary essay, the travel as geographical
\end{abstract}


displacement and spiritual experience, the relationship between the individual and history, and the moderately skeptical view of Western culture, present, in different degrees, in the three authors.

Keywords: literary essay, travel literature, Polish essay, Spanish essay, Spanish-American essay.

\section{Introducción}

Señalar que la obra ensayística de Zbigniew Herbert (1924-1998) no ha recibido, tanto por los especialistas como por el público culto en general, la atención que merece, se ha convertido casi en un lugar común ${ }^{1}$. Que dicha obra no sea cuantitativamente impresionante no explica, por supuesto, ese hecho, que tiene que ver, en parte, con la abrumadora presencia del corpus poético herbertiano, pero también con la propia naturaleza genéricamente incierta o indefinida del ensayo ${ }^{2}$. El objetivo central de este trabajo, que tiene carácter de esbozo comparativo, es establecer, tomando como base principal pero no exclusiva el tema de la escritura ensayística como un viaje o una errancia, lazos de afinidad entre ensayos de Herbert y los de dos de los más connotados prosistas en lengua española, Octavio Paz (1914-1998) y Rafael Argullol

1 En adelante se emplearán las siguientes abreviaturas para los libros de ensayos de Zbigniew Herbert: NMB, para Herbert (2008, original polaco: 1993), UBJ, para Herbert (2010, original polaco: 1962) y LJM, para Herbert (2013, original polaco: 2000).

2 Así, por ejemplo, en su breve pero sustancioso artículo en torno a la ensayística de Herbert, el crítico literario A. Karcz declara que se trata, en el caso de Herbert, de "un autor no especialmente conocido por sus ensayos"; no obstante, agrega de inmediato que "sus dos modestas colecciones de ensayos [Karcz se refiere solamente a UBJ y NMB, pues al momento de escribir su artículo sobre el poeta polaco aún no se había publicado LJM], inspiradas por sus viajes a Francia, Italia y Holanda", "le aseguran a Herbert un lugar entre los ensayistas más destacados del mundo" (Karcz, 1997: 385). 
(1949-) $)^{3}$. De forma más concreta, se propone el siguiente orden de exposición.

En el primer apartado se esboza, antes que una definición en sentido estricto, una caracterización del ensayo concebido como expresión literaria de la errancia, del viaje como vía de conocimiento y autoconocimiento -una idea compartida en lo esencial por los tres escritores bajo estudio. Luego, se comenta de modo más específico - expandiendo ideas sugeridas en la sección anterior- la importancia del tema del viaje -y nociones afines, como desplazamiento, nomadismo y vagabundeo- en tanto que núcleo articulador de varios de los ensayos de Herbert, Argullol y Paz. A continuación, se plantean observaciones en torno a otras cuestiones abordadas de manera semejante en sus ensayos por los tres autores, como la relación entre individuo y acontecer histórico, y la presencia de una posición moderadamente escéptica ante la historia y la cultura.

\section{El ensayo literario como género de la errancia}

En el ensayo como género literario se materializa, como lo ha explicado el crítico español José María Pozuelo Yvancos, "una attitude, un modo de proceder en la organización del discurso, un estilo, entendido como propiedad en la que convergen la personalidad del autor, su manera de ser, con la manera no exhaustiva, ni fundada en autoridades, sino asimilada y perspectivizada, la mirada desde la que abordar cuanto asunto trate" (2012: 171). A lo anterior aún se puede agregar otro elemento que llama inmediatamente la atención en el escrito ensayístico; a saber, la convergencia fundamental entre la figura del autor y el contenido de un tex-

3 Naturalmente se trata, en el caso de estos dos últimos escritores, de apenas una selección mínima de sus escritos ensayísticos, suficiente solo para los temas principales de este trabajo. De ahí la omisión de obras centrales, pero de extensión considerable, de Paz y Argullol, cuya inclusión habría demandado casi un comentario exclusivo, como habría sido el caso, por ejemplo, de Visión desde el fondo del mar (2010), de Argullol, o El arco y la lira (1956), de Paz. 
to con el que aquél se identifica por completo. De ahí la conexión elemental que existe entre la escritura ensayística y la experiencia de la libertad, aspecto que resalta todavía más al considerar el viaje como un modo de representar, mediante el movimiento físico, la modalidad discursiva del ensayo como acto libre y en curso.

De acuerdo con el ensayista catalán Rafael Argullol, existe una vinculación esencial entre el deseo humano de conocimiento y la estrategia escritural del ensayo, ya que, en efecto, "lo que más nos acerca a la experiencia del conocimiento es la tentativa: nos movemos por intentos" (2008: 10). El ensayo es, precisamente intento de conocer, por lo que para Argullol "adquiere un significado radical la afirmación de Montaigne acerca del ensayo, según la cual éste sería el ámbito literario que profundizaría más en la relación entre el hombre y el conocimiento porque nos introduce en la tentativa y en el experimento" (2008: 10).

Ahora bien, si hay un grupo de experiencias vitales que resume de manera ejemplar el gesto ensayístico de una búsqueda sin término, es el que tiene que ver con el viaje, la errancia, el nomadismo y el vagabundeo, es decir, con experiencias del movimiento y el cambio físico y geográfico, al inicio, pero que reelaboradas por la sensibilidad estética del artista-escritor, adquieren una dimensión espiritual que trasciende su carácter meramente físico.

La afinidad entre la escritura ensayística y el viaje errabundo, como sendas formas del avanzar a tientas, la ha resaltado el filósofo español Francisco Jarauta con palabras que resultan relevantes para lo que seguirá en este trabajo: "El ensayismo no oculta su dimensión errante. Y para utilizar una feliz expresión de Harold Bloom que lo define como un 'vagabundeo del significado', podríamos entenderlo con un viaje, una errancia entre la forma y su superación irónica, entre lo que Lukács llamaba forma como destino y la aporía de una forma como totalidad independiente" (Jarauta, 2005: 38).

Es decir, con la puesta en marcha de la escritura ensayística, un autor emprende un tipo de viaje que sabe de antemano no será rectilíneo sino quebrado y sinuoso; se trata, como también acota Jarauta, de un viaje textual "permanentemente interrumpido por una omnipresente accidentalidad” (Jarauta, 2005: 38). Pero 
la presencia de lo accidental no se visualiza como un defecto sino como un elemento que otorga espontaneidad y vitalidad -y en este punto van a coincidir Z. Herbert, O. Paz y R. Argullol-, tanto al desplazamiento físico como a su recreación literaria: "Es la interrupción irónica que se alimenta de la sorpresa de ver una y otra vez suspendida la idea de esencia o de absoluto, por el simple hecho del irrumpir de las cosas o de la vida. Este errar es justamente lo que acerca el ensayo a la vida" (Jarauta, 2005: 38).

En la concepción de la escritura ensayística como un tipo de viaje está pues implícita, como ya se sugirió al comienzo de este apartado, una defensa de la libertad. La actitud del ensayista constituye una postura que a menudo resulta contestataria de los excesos de la autoridad y el poder. Una posición intelectual que puede tener incluso carácter subversivo en la medida en que cuestione la legitimidad de aquellos obstáculos que impiden precisamente la 'movilidad' físico-intelectual, el movimiento de los cuerpos y las ideas.

La convergencia de términos como 'ensayo', 'viaje' y 'libertad' se apoya, desde luego, en una amplia concepción de la literatura que la identifica, como ha escrito Rafael Argullol, con una "metaforización ilimitada del viaje -limitado- de la vida. No importa que esta proyección metafórica se realice desde un escenario inmóvil ni, tampoco, que su artífice renuncie a todo desplazamiento físico: en todos los casos el escritor viaja bajo el imprescindible motor de la imaginación" (2013: 130). Pero más sobre esta temática en el siguiente apartado.

\section{Escritura ensayística y modalidades del viaje}

¿Cómo se manifiesta de manera más individualizada, en los tres autores seleccionados para su comparación en este trabajo, esta relación entre el ensayo como viaje y el viaje como representación físico-poética del impulso ensayístico? Para comenzar, en el caso de Zbigniew Herbert, el conjunto de ensayos que conforman los volúmenes UBJ y LJM, pueden ser inscritos con claridad en lo que se denomina, de modo muy general por supuesto, 'literatura de viajes'. 
Según la especialista en este subgénero literario, Beatriz Colombi, dicha literatura se ofrece "como una narración en prosa en primera persona que trata sobre un desplazamiento en el espacio hecha por un sujeto que, asumiendo el doble papel de informante y protagonista de los hechos, manifiesta explícitamente la correspondencia -veraz, objetiva- de tal desplazamiento con su relato" (2006: 13).

Además, en la literatura de viajes, los "componentes temáticos (desplazamiento en el espacio), enunciativos (coincidencia del sujeto de la enunciación y del enunciado) y retóricos (veracidad, objetividad, marcas de lo factual) guardan constancia a lo largo del tiempo" (Colombi, 2006: 13). Estas características apuntadas por la especialista argentina están presentes, sin duda, en los diversos ensayos de Herbert. Aunque, desde luego, los desplazamientos geográficos del poeta polaco por territorios holandeses, franceses e italianos, en realidad constituyen la base para otro tipo de viaje de significación más honda. Pues, como lo expresa de forma admirable otro conocido escritor-viajero, el italiano Claudio Magris, el viaje poético (o "viaje-escritura", como él la denomina), no se limita al desplazamiento físico y a su correspondiente descripción fiel:

El viaje-escritura es una arqueología del paisaje; el viajero -el escritor- desciende como un arqueólogo en los diferentes estratos de la realidad para leer también las señales escondidas bajo otras señales, para recoger el mayor número de existencias e historias posibles y salvarlas del río del tiempo, de la ola canceladora del olvido, casi construyendo una frágil arca de Noé de papel, si bien irónicamente consciente de su precariedad (Magris 2005: 7).

Considérese ahora algunos ejemplos de la obra ensayística de Herbert, Paz y Argullol que ilustran las ideas anteriores sobre la conexión de la experiencia del viajar con el movimiento de las ideas en la escritura ensayística.

En primer lugar, para Herbert, el viaje es, ante todo, una manera de compenetrarse física y espiritualmente con el lugar de destino, "el viajero ideal es aquel que puede entrar en contacto con la naturaleza, la gente, la historia -y también con el arte-; y hasta 
que no se conocen estos elementos que se funden entre sí no empieza el verdadero conocimiento del país a investigar" (NMB: 10).

El poeta viajero que Herbert encarna desea conocer a fondo la naturaleza viva de los sitios visitados, no solo la conservada y clasificada en museos y bibliotecas. De ahí que en la narración ensayística herbertiana esté ausente el pedantismo intelectual que solo se concentra en la contemplación y visita de ciertos objetos y lugares poseedores de algún pedigrí cultural: "Esta vez me permití el lujo de apartarme de las cosas 'serias e importantes' para poder comprar los monumentos, los libros y los cuadros con el sol autentico, el mar auténtico, la tierra auténtica" (NMB: 10).

Durante sus caminatas por ciudades y pueblos de Italia y Francia, Herbert siente predilección por el universo de las cosas concretas y sensibles, no por lo abstracto ni demasiado solemne. De ciertos lugares le atraen su carácter casi de seres vivos, como cuando se pregunta de Arlés lo siguiente: “¿Cómo describir una ciudad que no es de piedra, sino de carne y hueso? Tiene una piel cálida, húmeda y el pulso de un animal trabado" (UBJ: 47). A pesar de que el autor polaco ha escrito, basándose en sus numerosas visitas a museos y galerías, varios ensayos notables sobre diferentes obras de arte, lo cierto es que su primera reacción como visitante es evitar los espacios cerrados, precisamente como los museos, porque no dan una imagen fiel, viva, de la fusión de épocas y culturas:

Nuestros antepasados no tenían por costumbre crear museos como nosotros, no convertían los objetos antiguos en objetos expuestos en vitrinas cerradas. Los utilizaban en las nuevas construcciones, incorporaban directamente el pasado al presente. Por eso, visitar ciudades como Arlés, donde se entremezclan las piedras y las épocas, es mucho más edificante que el frío didactismo de las colecciones sistematizadas (UBJ: 54).

En los ensayos de Herbert es patente el deseo de dejar constancia de lo que se ha olido, visto y tocado; el ensayista busca ofrecer un testimonio viviente de sus experiencias. Así, escribiendo sobre los tres templos dóricos "mejor conservados en el mundo"; a saber: "la Basílica, el templo de Poseidón y el templo de Démeter", Herbert 
anota, recalcando de nuevo el carácter de experiencia eminentemente física y sensual-sensorial de su anhelada visita, estas palabras: "Ahora los veo por primera vez en directo, reales. Dentro de un rato podré ir allí, acercar la cara a las piedras, explorar su olor, pasar la mano por las muescas de las columnas" (UBJ: 33).

El contacto directo es insustituible para el ensayista polaco, toda descripción indirecta le resulta, por fuerza, incompleta y engañosa: "Hay que liberarse, purificarse, olvidar todas las fotografías que uno ha visto, las representaciones, las guías. Y también olvidar lo que me había repetido siempre sobre la pureza inmaculada y la grandeza de los griegos" (UBJ: 33).

Por otro lado, los desplazamientos de Herbert fortalecen su creencia en cierta cultura universal, ecuménica. Así, sus viajes a Holanda, por ejemplo, le recuerdan la conexión esencial de las épocas y los pueblos: ni las unas ni los otros están exentos de compartir extremos de lo bello y lo grotesco, grandes triunfos y también tragedias, lo sublime y lo terrible. Esto le permite afianzar una perspectiva relativista sobre el acontecer histórico.

No obstante, después de narrar la "fiebre del tulipán (la más grande locura botánica conocida)", el autor confiesa a sus lectores, que, si bien "tenemos una extraña predilección por aquello que rebasa el sentido común, y nos gusta ocuparnos de catástrofes que ocurren sobre el fondo de un paisaje agradable", su interés por dicha fiebre holandesa obedece a un motivo de mayor calado filosófico, pues, acaso dicho episodio, “'ino nos recuerda otras locuras, más amenazadoras, de la humanidad; locuras que se basan en la adhesión irracional a una única idea, a un símbolo, a una fórmula de felicidad?" (NMB: 87).

En otro de sus viajes, esta vez a Siena, el poeta errante observa sin disimulado desprecio los efectos del turismo de masas y la sociedad de consumo. Observa cómo, por ejemplo, los "guías gritan a los rebaños de turistas para que se den prisa. Granjeros sudorientos de un país lejano graban cada uno de los fragmentos del muro que muestra d- quien da las explicaciones y, obedientemente, se sumen en un éxtasis al tocar las piedras de siglos atrás". Efectivamente, en opinión de Herbert, los turistas contemporáneos no "tienen tiempo para mirar, están demasiado ocupados en fabricar copias” (UBJ: 105). 
En su interpretación de la experiencia del viajar en la obra de Z. Herbert, la investigadora Bożena Shalcross arriba a ciertas conclusiones que se pueden generalizar, de forma iluminadora, para los casos afines de Argullol y Paz. A juicio de dicha autora, el viajero herbertiano se lanza a una búsqueda individualizada de descubrimiento cultural que es, a la vez, de hallazgo identitario. Se trata de una doble revelación que le otorga al poeta pistas para comprender tanto sus orígenes o raíces específicos como la manera en que éstos se cruzan o intersecan con otras tradiciones nacionales. Sin duda, tal es el caso también de Argullol y Paz: búsqueda de lo 'exótico' que es a la vez pesquisa de raíces humanas comunes.

Pero todo lo anterior tiene que ver también con la cualidad espiritualmente iluminadora del peregrinaje que adopta el viaje, según la lectura de Shallcross, en la ensayística herbertiana. Para el autor polaco, en efecto, la posibilidad de viajar constituye un privilegio moral supremo, en la medida en que un solo individuo de una comunidad ha sido elegido para apreciar, en lugar de los ausentes, de los que por diversas razones se han quedado atrás, las grandes obras de la herencia cultural, ejemplos del "inagotable esplendor del mundo": "Como un peregrino religioso que representa por entero a su comunidad, [Herbert] se siente abrumado y al mismo tiempo fortalecido por un claro sentido de la misión y el deber" (Shallcross, 2002: 46).

Así pues, más que egocentrismo, orgullo y vanidad, lo que llena el alma del ensayista-poeta mientras transita de un sitio al otro, es, de acuerdo con la interpretación anterior, la humildad, la responsabilidad y el sentido del deber ante la tarea más bien descomunal que tiene ante sí. Estas son las palabras de Herbert:

Si he sido elegido -pensé- al azar, sin tener ningún mérito particular, debo dar sentido a esta elección y arrebatarle su casualidad y arbitrariedad. ¿Qué significa esto? Significa ponerme a la altura de la elección y convertirla en mi elección. Imaginar que soy un delegado o un embajador de todos los que han fracasado $y$, como buen delegado o embajador, olvidar el yo, y potenciar toda mi sensibilidad y mi capacidad de comprensión para que la Acrópolis, las catedrales y la Mona 
Lisa se reproduzcan en mi interior, siempre en la medida que lo permitan las limitaciones de mi mente y de mi corazón. Y así transmitir lo que he comprendido (LJM: 128-129).

Puesto que ya se ha insistido de forma muy general en las afinidades entre los tres autores, ¿cómo se percibe ahora, a partir de ejemplos textuales más concretos, el viaje y el viajar desde la ensayística de Rafael Argullol y Octavio Paz en comparación con la de Zbigniew Herbert? Existe, ante todo, una total convergencia en considerar que el viaje adquiere, desde la experiencia del escritor-poeta, una dimensión especial que lo hace trascender su cualidad inmediata de desplazamiento físico.

En primer término, R. Argullol concuerda con Herbert en descalificar como espiritualmente empobrecedor el simple viaje turístico. Escribe dicho autor: "Por eso no se puede juzgar al escritor-viajero desde la óptica del turista. Éste sabe, en el mejor de los casos, por que va; aquél va, incluso sin salir de su casa, porque sabe. En el escritor-viajero prevalece la dimensión mítica sobre lo real, por más que las experiencias físicas del viaje puedan modificar elementos esenciales de su percepción” (2013: 131).

De ahí que el autor catalán subraye que "la auténtica geografía a la que se enfrenta el escritor-viajero" sea en realidad una "geografía mítica", "cuyas coordenadas alteran poderosamente el significado del itinerario. El eje de la brújula se orienta según el magnetismo que le dicta el espíritu" (2013: 131). La idea de un poeta errante por territorios míticos que afectan y modifican su vida espiritual, guarda relación con la idea del viaje como peregrinación, como experiencia iniciática, presentada anteriormente en relación a Herbert. Sobre el viaje como experiencia que altera la subjetividad del escritor, acota Argullol:

Éste es, en definitiva, el sentido de la geografía mítica que anticipa la posibilidad de ulteriores aventuras en las geografías de la realidad. De ahí que todos los itinerarios del escritor-viajero impliquen, en primera instancia, una componente iniciática: un aprendizaje, una prueba, un conocimiento. También, como complemento, una voluntad de 
cambio que se manifiesta en la suposición de que el viaje entrañará, para su protagonista, una alteración de la existencia (2013: 132).

En segundo término, es notable que, para Argullol, el ensayo o literatura de viajes constituya también una suerte de estrategia de elaboración de mundos posibles. El escritor recurre al depósito de la memoria y con base en los materiales ahí dispuestos -acopiados a lo largo de sus recorridos por aquellas "geografías míticas"- reconstruye a su modo el sentido del mundo. Un mundo al que dota -románticamente- de mayor riqueza y variedad:

La literatura es el registro de nuestros viajes a través de las memorias, no tanto del mundo tal y como es -pues resulta inconcebible tratar de expresarlo- sino según lo que tempranamente percibió Aristóteles: el mundo como pudo, puede o podría ser. Por tanto, la literatura no es el registro empírico de la realidad, sino el registro de lo que eso que llamamos 'realidad' puede ser en potencia (Argullol, 2008: 52).

Un magnífico ejemplo de lo que puede significar esa reconstitución poética de la realidad mediante el recuerdo y la escritura - con la que coincidirían tanto Z. Herbert como O. Paz-, lo ofrece el conjunto de ensayos cortos titulado "Imagen y mito del Mediterráneo". En este trabajo, R. Argullol enfatiza que el viajero sensible no solo observa con atención el paisaje circundante, sino que también en cierto sentido se ve interpelado, observado por éste.

El artista errante se mueve en territorios que actuarán sobre él enriqueciéndolo, a condición de que exista el estado espiritual propicio para ese dejarse poseer no por las fuerzas manipuladoras del estéril turismo de masas, sino por las vivas de la naturaleza. Los paisajes del Mediterráneo son ejemplos para Argullol de estos espacios interpelantes, evocadores de mitos ancestrales que reviven en el escrito ensayístico-poético:

La mirada del Mediterráneo es esencialmente transfiguradora: nos conduce de la imagen concreta a la imagen secreta 
y universal, nos conduce del presente al origen. Amortigua nuestro sentimiento de orfandad transportándonos a la tierra matriz, al mar originario. El magnetismo poderoso del Mediterráneo estriba en su carácter fundador (1993: 174).

Otra muestra característica del talante espiritual del viajero-narrador de los ensayos de Argullol considerados aquí, lo constituye el texto "Pompeya para una travesía solitaria". Lo fundamental de este texto es el modo en que su autor evoca una naturaleza que domina al viajero y que no cede sin más sus secretos al observador superficial. Su autor utiliza con frecuencia adjetivos como "indescifrable", "inexplicable" o "mistérico" para referirse a una ciudad y un entorno que no se dejan apresar por la mirada del caminante casual. En Herbert y Paz se encuentra una actitud similar de hondo respeto ante ciertos lugares y paisajes que sobrecogen al viajero.

Pero esta especial actitud o disposición anímica del viajero sensible no hay que confundirla con una simple actitud de añoranza por un pasado ya definitivamente perdido, sino con la posibilidad de acoger en profundidad -es decir, de re-vivir, en cierto sentido- la herencia del pasado: "Lo fundamental es que permanezca aquella herencia capaz de suscitar el viaje de la imaginación $y$, por tanto, de avivar nuestro deseo de dirigirnos a un espacio que está más allá de las fronteras de nuestra cotidianeidad" (Argullol, 1993: 198).

En suma, desde el punto de vista de R. Argullol en sus ensayos sobre viajes, se requiere una apertura espiritual muy especial para que el paisaje renazca y se reproduzca en alguna medida, con sus propias condiciones, en el alma del paseante solitario. No obstante, esta especie de conexión dialógica con el paisaje no será siempre directa, y la reproducción espiritual será siempre imperfecta -punto igualmente compartido por Herbert y Paz-. El conocimiento que incluso el viajero más atento y sensible derive de sus esfuerzos no poseerá un carácter integral:

Cuando el solitario visitante parta de Pompeya tendrá una clara conciencia de que la ciudad apenas se ha desvelado. En 
la frontera donde se acaban sus calles excavadas, empieza el subsuelo que contiene otros secretos, otras memorias, otros sueños. Tendrá la conciencia de que aquella será una ciudad inacabada para siempre, pues siempre se encarnará en nuevas ciudades, en nuevas máscaras con las que fascinar y confundir a sus contempladores (1993: 204).

En el caso de Octavio Paz, su voluminosa obra ensayística comparte elementos significativos con la de Herbert y Argullol en relación con el significado del viaje y su recreación poética. En dichos textos se comprueba la importancia que tuvo para su arte literario la experiencia de viajar concebido como una experiencia de enriquecimiento personal y comunicación inter-cultural. O sea, como se comentó en el caso de Herbert, una forma de peregrinación espiritual.

Considérese en primer lugar el célebre ensayo-poema de Paz, El mono gramático, donde se sugiere el carácter primario de circularidad que ostenta todo viaje de (auto)descubrimiento. Esto se muestra especialmente en un texto híbrido como éste de 1974, que en cuanto ensayo propone un avance de ideas que va configurando su propia ruta nunca finalizada de autodescubrimiento, pero que en cuanto poema sí logra constituir un mundo propio en cuyo interior reina, sutil paradoja hábilmente desarrollada por Paz, el eterno presente de la poesía:

Dichas o escritas, las palabras avanzan y se inscriben una detrás de otra en un espacio propio: la hoja de papel, el muro de aire. Van de aquí para allá, trazan un camino: transcurren, son tiempo. Aunque no cesan de moverse de un punto a otro y así dibujan una línea horizontal o vertical (según sea la índole de la escritura), desde otra perspectiva, la simultánea o convergente, que es la de la poesía, las frases que componen el texto aparecen como grandes bloques inmóviles y transparentes: el texto no transcurre, el lenguaje cesa de fluir (2001: 135).

El texto paciano de 1974 llama la atención sobre el carácter fluido e inacabado de una variante particular del ensayo, desarrollado con fina intuición por el autor mexicano. Se trata de un 
escrito que exhibe orgulloso su condición híbrida y errante, tanto de boceto de escritura como de escritura de bocetos. Además, $E l$ mono gramático se centra en la figura de un poeta caminante que emprende, como se vio antes con Herbert y Argullol, una suerte de peregrinación por territorios que son a un tiempo los del lenguaje y los de un lugar físico determinado -pero transfigurado, gracias a esa especial mezcla de palabra poética y reflexión ensayística propia de Paz, en sitio de iluminación estética-.

Como escribe un conocido teórico del ensayo literario sobre el libro de Paz: "Ese texto [El mono gramático] es un ensayo con funciones poéticas o tal vez un poema con funciones de ensayo. Y la poesía de Paz, ¿no es un intento de cristalizar en imágenes posibles respuestas a esos interrogantes que corretean, siempre al borde de la poesía, a lo largo de sus ensayos?” (Alazraki, 1982: 15).

El modo deslumbrante en que el Nobel mexicano logra crear desde la escritura un mundo vivo, orgánico, de rasgos animales y vegetales, en crecimiento y expansión, apunta a la correspondencia entre el mundo de los seres vivos y el de los signos de escritura a la que se alude en el siguiente fragmento. El texto también muestra al ensayista-poeta en una especie de viaje exploratorio dentro de un laberíntico microcosmos de palabras:

Manchas: malezas: borrones. Tachaduras. Preso entre las líneas, las lianas de las letras. Ahogado por los trazos, los lazos de las vocales. Mordido, picoteado por las pinzas, los garfios de las consonantes. Maleza de signos: negación de los signos. Gesticulación estúpida, grotesca ceremonia. Pletórica térmica en extinción: los signos se comen a los signos. Maleza se convierte en desierto, algarabía en silencio: arenales de letras. Alfabetos podridos, escrituras quemadas, detritos verbales. Cenizas. Idiomas nacientes, larvas, fetos, abortos. Maleza: pululación homicida: erial (Paz, 2001: 39).

En un pasaje de otra obra dedicada a rememorar distintos viajes y experiencias por geografías muy distantes de su patria mexicana, en concreto por diversas regiones de la India-Vislumbres de la India (1995)-, Paz se detiene a considerar, de un modo similar 
al ensayista polaco, el impacto de lo sensorial sobre el peregrino en tierras 'exóticas' -en el caso específico que sigue: Bombay-. La perspectiva que el ensayista mexicano asume de manera consciente es también, como en el caso de Herbert en tierras francesas o italianas, no la del turista de actividades pre-programadas, sino la del flâneur que busca comprender otras culturas no solo desde el mundo de las bibliotecas y museos, sino y sobre todo desde una inmersión en su multiforme vida cotidiana: "Tomé un taxi y recorrí distritos desiertos y barrios populosos, calles animadas por la doble fiebre del vicio y del dinero. Vi monstruos y me cegaron relámpagos de belleza. Deambulé por callejuelas infames y me asomé a burdeles y tendejones: putas pintarrajeadas y gitones [sic] con collares de vidrio y faldas de colorines" (Paz, 2012: 16). Aunque rendido por sus vagabundeos, el poeta regresa a su hotel solo para verse de nuevo atraído, irremediablemente, por el tumulto urbano: "Tomé otro taxi y volvía a las cercanías del hotel. Pero no entré; la noche me atraía y decidí dar otro paseo por la gran avenida que bordea a los muelles" (ibidem).

Queda claro, según lo visto y comentado, que para los tres autores la narración de un viaje mediante el recurso del ensayo desborda con creces los límites de la pura descripción anecdótica y pintoresquista, que se puede hallar en numerosos ejemplos de la literatura divulgadora de intención más comercial. La descripción de lugares en Herbert, Paz y Argullol equivale a una reconstrucción lírica que surge desde los laberintos de la memoria, y que no engaña a los lectores haciéndoles creer en la correspondencia fotográfica de lo escrito con lo vivido y visitado físicamente.

Lo leído en los ensayos de viajes de los tres autores constituye un extracto poéticamente tamizado de actos y movimientos físicos, tanto como de actos y movimientos de lectura y meditación. Así, mientras que, por un lado, los viajes físicos de estos poetas fueron realizados, en su mayoría, en soledad: es casi siempre uno (el autor) el que camina y ve; por otro lado, la reconstrucción ensayístico-poética de lo sentido y vivido demandó otro tipo de itinerario en compañía de otros: autores y textos, compañeros imaginarios de travesía por los senderos de la memoria y la reflexión. 
En síntesis, puede afirmarse que, en los ensayos de Herbert, Paz y Argullol, y como lo recuerda la especialista María Rubio, "el referente" central de los textos "deja de ser únicamente un viaje realizado en un tiempo concreto con unos motivos particulares para ser la suma de sucesivos encuentros del viajero con un espacio, enriquecidos por las visiones que otros tuvieron antes que él, producidos en distintos momentos de su vida [...]" (Rubio, 2008: 158).

Con todo y lo significativo que es el tema del viaje en la obra ensayística de Herbert, Paz y Argullol, no constituye, claro está, el único que ha acaparado la atención de los tres autores. Tratándose de autores poseedores de una amplia cultura humanista y una insaciable curiosidad intelectual, no puede sorprender que en sus ensayos se aborde, explícita o implícitamente, otro número importante de cuestiones de índole filosófica y política -en sentido amplio-. A ellos se abocarán los comentarios en la siguiente sección del trabajo.

\section{Individuo e historia, escepticismo y cultura}

En los ensayos de los tres autores es visible una posición compartida, moderadamente escéptica y relativista de la historia y de la producción cultural del ser humano. Así, por ejemplo, los tres autores son conscientes de que, por desgracia, las grandes tragedias de la historia no impedirán la repetición de las peores manifestaciones de la hibris y el afán autodestructivo. Pero en Herbert sobresale, como ha sido señalado por diversos intérpretes -mucho más que en los otros dos escritores-, una particular mirada crítica hacia las vicisitudes de la dinámica política y social del siglo pasado. Ahora bien, se trata de una actitud que en su caso se fundamenta en un distanciamiento de la realidad mediante la ironía, una estrategia que el poeta, aunque también aplica de forma autocrítica a su propia persona, no lo lleva, sin embargo, a una postura derrotista o nihilista 4 .

4 Incluso, A. Karcz escribe que la ironía es el "recurso literario favorito de Herbert" (1997: 385). 
Es digno de nota que Herbert sienta predilección en sus ensayos por la exposición de ciertos destinos individuales en la historia antes que por la de los grandes movimientos de masas. Acaso porque desconfía de la forma en que tales masas son continuamente manipuladas por sus líderes. Por ejemplo, cuando detalla las razones que lo llevaron a escribir su ensayo sobre las catedrales góticas, anota que la idea se le ocurrió en Chartres, pero la perspectiva que iba a asumir dista mucho de la que se concentra en la historia social de los grandes acontecimientos. Su perspectiva se enfoca en aspectos mucho más concretos -con un perfil más modesto-. En su texto los protagonistas son las herramientas, los materiales y los hombres implicados en semejante empresa. Por eso,

en lugar de escribir sobre los vitrales que moldean la luz, igual que el canto gregoriano moldea el silencio, y sobre las misteriosas quimeras que sueñan sobre el abismo de los siglos, tal vez podría indagar cómo había llegado hasta allí arriba aquella piedra. En consecuencia, debería escribir sobre los constructores, los picapedreros y los arquitectos, pero no sobre qué albergaban en sus almas cuando alzaban la catedral sino qué materiales y qué herramientas utilizaban, cómo y cuánto ganaban. Un objetivo modesto, como si un coleccionista de libros escribiera sobre el gótico, pues la Edad Media también enseña la modestia (UBJ: 124-125).

Quizá la concentración en las historias individuales -con sus extremos de grandeza y ridículo- ha fortalecido en Herbert el distanciamiento irónico. Pero, como muy bien ha explicado este punto el crítico y poeta Stanisław Barańczak, en la obra de Herbert hay ciertos límites en el empleo de la ironía como arma de combate y denuncia. Aunque el teórico polaco tiene en mente, como se verá en un momento, sobre todo la poesía de Herbert, sus conclusiones pueden generalizarse también para el espíritu que impera en su prosa: "En contraposición a la obra de los románticos irónicos típicos, la poesía de Herbert se caracteriza por la presencia de ciertos imponderables, que la ironía no puede dañar y que ni siquiera intenta rozar" (Barańczak, 1987: 115). Se trata, según la razonada interpretación de S. Barańczak, de ciertos “valores intocables" como 
la lealtad, la fidelidad y la fe, que constituirían en el presente, para Herbert, los últimos baluartes morales en un mundo víctima del despojo histórico y la manipulación ideológica.

De hecho, en varios de sus textos, Herbert se permite señalar -dentro de las circunstancias de la censura efectivas en su paísciertas incómodas coincidencias históricas. El modo, por ejemplo, en que en la antigua Atenas la imposición del silencio y el corte de la libertad de expresión -en vigor después de la guerra contra Samos-, demandó la creación de una imagen oficial de armonía civil que no debía reflejar, justo como no lo puede hacer en ninguna sociedad sometida al autoritarismo político, el verdadero sentir de sus habitantes.

Al respecto escribe Herbert en "La cuestión de Samos" (1972): "Aquella limitación drástica de la libertad de palabra demuestra que el verdadero estado de ánimo de la población debía de ser muy distinto al entusiasmo y al optimismo oficiales" (LJM: 201)5. En estas palabras y las que se citan a continuación, se puede ver una clara posición a favor de uno de aquellos "valores intocables" a que hace referencia S. Barańczak; a saber, el ansia de libertad que tarde o temprano se impondrá a quienes momentáneamente la mantienen sofocada. Escribe Herbert: “¿Qué moraleja se desprende del relato sobre el sometimiento de la isla de Samos? Creo que es la siguiente: cuando regresan de la guerra, los invasores traen escondido entre los pliegues de sus uniformes y en las suelas de sus botas un germen que contagiará a su propia sociedad y corromperá sus propias libertades" (LJM: 202).

Por comparación, el empleo del distanciamiento irónico no es tan conspicuo en el caso de los dos ensayistas hispánicos. Pero lo que sí comparten con Herbert es cierta añoranza por aquellos imponderables cuya presencia tácita es tan importante en la obra

5 En torno a los diversos estratos de la confrontación de Herbert y otros intelectuales con la censura en Polonia, J. M. Coetzee opina que: "La relación de Zbigniew Herbert con la censura de estado polaca, durante los años en que esa censura estaba en el poder, era atípica" (1990/1991: 160). Las razones aducidas por Coetzee en su artículo son persuasivas. 
del autor polaco. Es decir, en los tres escritores sobresale un anhelo de unión con la cultura humana y sus productos más nobles, más allá del tiempo y el espacio. Los tres también abogan por una inmersión cosmopolita en los frutos de la cultura. Se trata de un impulso que unifica las reflexiones de Herbert, Argullol y Paz sobre los más variados temas.

El final del ensayo de Herbert sobre Lascaux, en donde el viajero polaco narra su despedida de ese sitio histórico, constituye un excelente ejemplo de esto último. Herbert, lanzando una mirada retrospectiva a lo visto y meditado en las penumbras de Lascaux, reafirma su pertenencia a la familia humana, cuyos antiquísimos parientes crearon las sobrecogedoras imágenes que habitan ese sitio:

Volví de Lascaux por la misma carretera por la que había ido. A pesar de que había mirado, como se dice habitualmente, en el abismo de la historia, no tenía la sensación de volver de otro mundo. Nunca antes me había ratificado en la confortadora convicción de que soy un ciudadano de la Tierra, heredero no tan sólo de los griegos y de los romanos, sino de casi lo infinito (UBJ: 26).

Interesantemente, la defensa del cosmopolitismo y el universalismo cultural en los tres ensayistas quizá pueda entenderse, en parte, como una reacción de intelectuales provenientes de países no enteramente asimilados a cierta 'normalidad' cultural, europeo-occidental. Países visualizados, a veces, como territorios más bien fronterizos, cultural, política y mentalmente 'al margen', o casi, de corrientes artísticas y filosóficas dominantes. ¿ No representan acaso España ('la exótica'), México ('nación tercermundista') y Polonia ('el otro mundo, el eslavo') naciones cuyos artistas e intelectuales deben realizar un esfuerzo adicional para ser plenamente admitidos en el universo artístico, filosófico y científico europeo-occidental?

En principio, en varios de los ensayos de R. Argullol se siente la presencia no tanto de una actitud irónica ante la historia y la cultura, sino de una cierta añoranza romántica por algunas experiencias ligadas a lugares y eventos del pasado que se revelan, aquí 
y ahora, como irrecuperables. Esto obliga al ensayista a meditar sobre las posibilidades mismas del arte y la literatura, es decir, acerca del papel del artista y el escritor, en un mundo como el actual en el que ciertos ideales y valores parecen sufrir un proceso de decadencia e incluso extinción progresiva.

En esas circunstancias, al artista le corresponde recuperar cierto sentido mítico de la realidad. Con palabras del autor -que, aunque referidas a la figura del "poeta", en realidad es forzoso extender al ensayista, puesto que en el escritor catalán ambas se funden en una sola voz-: "Expresando fe por lo que nunca existirá y nostalgia por lo que nunca ha existido, el poeta, como simulador absoluto, recrea el mito e incita al viaje" (Argullol, 1993: 10).

Dichas palabras guardan cierta relación con la propuesta de lectura de S. Barańczak a propósito de Herbert. Está claro que ninguno de los tres autores aquí estudiados puede considerase un apologeta del utopismo -el diseño de sociedades perfectamente armónicas-. La dimensión utópica, la ilusión de perfección que genera en el espíritu, no puede ocultarle al artista-poeta que su obra, en tanto que intento de capturar lo inasible, constituirá a sus ojos, según escribe Argullol en "La poesía como viaje utópico", "un fruto fallido, dolorosamente incompleto e, incluso, inaceptable" (1993: 36).

No obstante, cierto utopismo mínimo sí es detectable en algunos de los textos de Argullol, en la medida en que para él -pero también para los otros dos poetas- es fundamental conservar y solidificar aquel compromiso de fidelidad con la condición humana, sobre la que escribe S. Barańczak al final de su libro, afirmando que se halla "suspendida entre la fragilidad y la perfección, la experiencia y el mito, la herencia y el desheredamiento" (1987: 135). Por otro lado, R. Argullol también nos recuerda un punto con el que Paz coincidiría plenamente; a saber, que: "La historia requiere ser transfigurada por la poesía para ser soportable e, incluso, incitante. De un modo semejante las construcciones humanas deben moldearse a través de la metamorfosis del arte para convertirse en objeto de goce" (1993: 198).

El autor catalán es consciente -al igual que Herbert y Paz- de la permanente tentación de la utopía en la historia, el deseo de 
levantar, con el apoyo de Grandes Ideas, ciudades o estados ideales. Por desgracia, esos sueños se convierten por lo general y muy pronto en pesadillas para individuos concretos. De hecho, aclara: "Estamos viviendo la resaca de la transformación de la ciudad celeste en ciudad infernal, aquella que podríamos traducir a través de ciertos nombres clave del siglo XX como pueden ser los campos de concentración nazis, el Gulag o Hiroshima, o a través de la posibilidad misma de la destrucción de la humanidad por sus propios medios" (Argullol, 2008: 80).

Con todo, las advertencias sobre los peligros del sueño utopista no deben hacer pensar que Argullol recomiende como contra-receta la pasividad, la inacción y el "dejar hacer”. En modo alguno. Considérese tan solo uno de los ensayos más claros en torno a esta problemática, "El ciudadano K. ante el nuevo Moloch". En este trabajo, su autor advierte sobre el peligro de claudicar ante aquella pesadilla imaginada por Kafka, consistente en aceptar como inevitable la escisión entre una realidad enajenada, fetichizada, y un yo "expulsado hacia sí mismo". En esta tesitura la única actitud coherente es la rendición al "Aparato", es decir a un tejido técnico-burocrático que tiende cada vez más a arrebatarle poder decisorio al individuo; éste pasa del hacer al "dejar hacer" -expresión que Argullol (1993: 156) retoma de Robert Musil-. Con sus palabras:

Tanto en el hombre sitiado en el Aparato, expuesto por Kafka, como en el 'hombre sin atributos' de Musil se apunta a una tendencia a considerar la realidad como una escena inconmovible que se autorreproduce según leyes inalterables, casi indescifrables, y frente a la cual el ser humano cede a la inacción. Y en este sentido el hombre es un sujeto que espera mas no actúa" (Argullol 1993: 157).

Para Octavio Paz, la defensa de la utopía como dogma intelectual y social es incompatible con la defensa del ideal democrático que debe estar impregnado de cierto pragmatismo político -favorecedor del compromiso razonable y la negociación- como antídoto contra la intransigencia de los absolutos, o, como él mismo dice, las 
"soluciones globales". De ahí que, en su opinión: “La declinación de las ideologías que he llamado meta-históricas, es decir, que asignan un fin y una dirección a la historia, implica el tácito abandono de soluciones globales. Nos inclinamos más y más, con buen sentido, por remedios limitados para resolver problemas concretos. Es cuerdo abstenerse de legislar sobre el porvenir" (Paz, 1990a: 485).

Este acento pragmático del pensamiento social de Paz, la apelación al diálogo y el compromiso, así como una preferencia por cierto relativismo de las ideas y una repulsa del autoritarismo ideológico, queda completamente claro en el siguiente fragmento del autor: "La violencia exacerba las diferencias e impide que unos y otros hablen y oigan; el monólogo anula al otro; el diálogo mantiene las diferencias, pero crea una zona en la que las alteridades coexisten y se entretejen. El diálogo excluye al ultimátum y así es una renuncia a los absolutos y a sus despóticas pretensiones de totalidad: somos relativos y es relativo lo que decimos y lo que oímos" (1995: 92).

No obstante, en diversas ocasiones el escritor mexicano se ha atrevido a otear el horizonte del futuro, no solo mexicano o latinoamericano, sino incluso mundial. Partiendo de su conocida postura crítica ante una concepción ingenua del progreso, las elucubraciones históricas de Paz van más lejos que las de los otros dos autores en su intención admonitoria sobre la responsabilidad humana por el curso de la historia:

En la segunda mitad del siglo XX el fin del mundo se ha convertido en un asunto público y de la exclusiva competencia de los hombres y sus actos. Ni demiurgos ni fuerzas naturales: los hombres serán los únicos responsables de la extinción o de la supervivencia de su especie. Ésta es la gran novedad histórica de nuestro siglo. Una novedad absoluta y que puede significar el fin de todas las novedades (1998: 34).

Está claro que Paz, al igual que Argullol y Herbert, se opone a la divinización de la Historia. Para bien y para mal los únicos responsables por el acontecer social son los seres humanos; el problema es que, con frecuencia, ellos mismos han querido encarnar algo así como el Espíritu de la Historia, con resultados catastró- 
ficos. Según Paz, es preciso reconocer de una vez por todas que: "La historia es nosotros, los hombres. Divinizar a la historia es divinizarnos a nosotros mismos, criaturas mortales y falibles. La historia es imperfección, fracaso y crimen por ser la obra de seres imperfectos: nosotros mismos" (1990b: 159).

Octavio Paz, Zbigniew Herbert y Rafael Argullol comparten una visión moderadamente escéptica de la historia y la vida social; se trata de una visión que acepta con lucidez, como dice Paz, "la conciencia trágica del hombre", es decir, el estar suspendido entre los extremos del bien y el mal: "La historia está hecha por los hombres y los hombres son tiempo, criaturas mortales e incompletas. Las verdades absolutas, en caso de que existan, no son de orden histórico. Buscar en la tierra la perfección del paraíso fue y es el trágico error de la edad moderna (Paz, 1993: 240).

La aceptación más o menos serena de la finitud e inestabilidad de las obras humanas constituye el marco común que comparten Herbert, Argullol y Paz. Desde el horizonte de la fragilidad humana los tres autores observan y valoran el curso histórico y los frutos de la cultura. En los textos de los tres ensayistas el narrador-observador se enfrenta con el mundo de los objetos, y ante todo con ciertas obras de arte que son interrogadas por el autor: monumentos, ruinas, esculturas, pinturas, etc. En ellas, los ensayistas-poetas descubren las huellas y trazos imborrables de las contradicciones inherentes a la condición humana, sus grandezas y miserias, sus aspiraciones de absoluto y perfección, tanto como su apego a bienes puramente materiales y temporales. Los impulsos creativos de ciertos individuos se enfrentan a corrientes y movimientos colectivos con los que o bien están en sintonía o bien en franca desavenencia. Una realidad cultural y social, en fin, marcada por siempre por la ambivalencia y la tensión.

\section{Conclusión}

Los textos de Zbigniew Herbert, Rafael Argullol y Octavio Paz citados y comentados en este trabajo son ejemplos eminentes de las posibilidades expresivas del ensayo literario. En tanto que for- 
ma de la escritura que tiende a desbordar fronteras genéricas, el ensayo busca instaurar un espacio escritural propio, articulado, fundamentalmente, en torno a actos de reflexión continua sobre el mundo. De hecho, al disponerse a ensayar el escritor emprende un viaje muy especial que no transcurre en espacios exteriores ni en forma rectilínea, sino en los internos de la imaginación y la memoria, y además de forma discontinua, fragmentada o sinuosa.

Pero esa travesía que el ensayista emprende de la mano de su escritura por los territorios de la fantasía y el recuerdo no lo aleja por fuerza de su entorno social concreto. Por lo menos la ensayística de Herbert, Argullol y Paz en modo alguno constituye un ejercicio de narcisismo disimulado, menos aún de escapismo estético. Al contrario, en estos autores la escritura de ensayos se descubre como una forma muy especial de autodisciplina artística que les sirve para revitalizar su compromiso con ciertos valores cardinales, como la libertad y la solidaridad, la lucha por la justicia social y la tolerancia intelectual, y todo ello ligado con los problemas más apremiantes de la modernidad.

\section{BIBLIOGRAFÍA}

Alazraki, J. (1982), "Tres formas del ensayo contemporáneo: Borges, Cortázar, Paz”, Revista Iberoamericana XLVIII, 118-119 (enero-junio): 18-36, https://revista-iberoamericana.pitt.edu/ojs/index.php/Iberoamericana/ article/viewFile/3678/3850 (acceso: 29.05.2017).

Argullol, R. (1993), Territorio del nómada, Barcelona: Destino.

Argullol, R. (2008), Aventura. Una filosofía nómada, Barcelona: Acantilado.

Argullol, R. (2013), Maldita perfección. Escritos sobre el sacrificio y la celebración de la belleza, Barcelona: Acantilado.

Barańczak, S. (1987), A Fugitive from Utopia. The Poetry of Zbigniew Herbert, Cambridge: Harvard University Press.

Coetzee, J. M. (1990/1991), "Zbigniew Herbert and the Figure of the Censor", Salmagundi 88/89, 25 $5^{\text {th }}$ Anniversary Issue (fall 1990-winter 1991): 158-175.

Colombi, B. (2006), “El viaje y su relato”, Latinoamérica. Revista de Estudios Latinoamericanos 43: 11-35, http://www.redalyc.org/pdf/640/64004302. pdf (acceso: 29.05.2017). 
Herbert, Z. (2008), Naturaleza muerta con brida. Ensayos y apócrifos, trad. X. Farré, Barcelona: Acantilado.

Herbert, Z. (2010), Un bárbaro en el jardín, trad. X. Farré, Barcelona: Acantilado.

Herbert, Z. (2013), El laberinto junto al mar, trad. A. Rubio, J. Sławomirski, Barcelona: Acantilado.

Jarauta, F. (2005), "Para una filosofía del ensayo", en: V. Cervera, B. Hernández, M. Adsuar (eds.), El ensayo como género literario, Murcia: Servicio de Publicaciones, 37-40.

Karcz, A. (1997), “Zbigniew Herbert”, en: T. Chevalier (ed.), Encyclopedia of the Essay, Chicago-London: Fitzroy Dearborn Publishers, 385-386.

Magris, C. (2005), "Desplazamientos”, Revista Revisiones 1: 3-14, http:// dadun.unav.edu/bitstream/10171/8535/1/REV_1_01.pdf (acceso: 29.05.2017).

Paz, O. (1990a), "La búsqueda del presente”, en: J. Skirius (comp.), El ensayo hispanoamericano del siglo XX, 5 ed., México: FCE, 475-487.

Paz, O. (1990b). In/mediaciones, 3 ed., Barcelona: Seix Barral.

Paz, O. (1993), Itinerario, México: FCE.

Paz, O. (1995), Pequeña crónica de grandes días, México: FCE.

Paz, O. (1998), Tiempo nublado, 2 ed., México: Seix Barral.

Paz, O. (2001), El mono gramático, 4 ed., Barcelona: Seix Barral.

Paz, O. (2012), Vislumbres de la India, Barcelona: Seix Barral.

Pozuelo Yvancos, J. M. (2012), “'Figuración del yo' frente a autoficción”, en:

A. Casas (ed.), La autoficción. Reflexiones teóricas, Madrid: Arco Libros, 151-173.

Rubio Martín, M. (2008), "Nuevas cartografías del libro de viajes contemporáneo: la cultura especular”, Letras 57-58: 149-162, http://bibliotecadigital.uca.edu.ar/repositorio/revistas/nuevas-cartografias-libro-viajes-contemporaneo.pdf (accesso: 29.05.2017).

Shallcross, B. (2002), Through the Poet's Eye: the Travels of Zagajewski, Herbert, and Brodsky, Evanston: Northwestern University Press. 